\title{
THE PROMISING RESPONSIBILITY OF ICT IN TEACHING-LEARNING PROCESS DURING COVID-19
}

\author{
Allysa Ashley M. Palaming \\ Perpetual Help College, Malasiqui, Pangasinan, Philippines
}

Article DOI: https://doi.org/10.36713/epra9660

DOI No: 10.36713/epra9660

\begin{abstract}
The present paper attempts to analyze the effects of COVID-19 Pandemic on multiple dimensions of human life especially the instructional technologies, the emergence of the role of ICT and other alternative technologies which have provided newer models in Teaching- Learning process gradually supplanting the conventional methods of teaching-learning process. The Nano Architecture Mobile Oriented Digital Institute (NAMODI), specific provisions in the National Education Policy, 2022 regarding ICT and its role in Indian Education system of the new millennia are other important components of the study. Web reports, Academic research, scholarly reviews and articles, recent studies, surveys conducted by the individuals as well as socio-cultural groups and organizations online, academic institutions etc. have been incorporated in the present study to validate the proposed topic.It's not merely the negative impact of COVID-19, but also a futuristic approach that has ushered due to COVID-19 in the Education system and the pedagogical technologies, has also been included in the paper.
\end{abstract}

KEY-WORDS: COVID-19 Pandemic, Instructional Technologies, New Education Policy, 2022

\section{INTRODUCTION}

The onslaught of the COVID-19 (Coronavirus) pandemic has adversely affected the entire human life disrupting all human activities, world economy sliding down steeply, millions of affected people have been killed due to the spread of this disease. The most common symptoms of this viral infection are fever, cold, cough, bone pain and breathing problems, and ultimately leading to pneumonia. This, being a new viral disease affecting humans for the first time, vaccines are not easily available. Thus, the emphasis is shifted on precautions suchas extensive hygiene protocol (e.g., regularly washing of hands, avoidance of face to face interaction etc.), social distancing, and wearing of masks, and so on. This virus is spreading exponentially region wise. Countries are banning gatherings of people to the spread and break the exponential curve. Many countries are locking their population and enforcing strict quarantine to control the spread of the havoc of this highly communicable disease. Human life, socio-cultural behavior, domestic violence, dislocation and trauma of migration and homelessness, emerging new life style, dietary habits and health awareness, alternative modes of teaching learning process, economic activities, social behavior, international relations and diplomacy, commerce and manufacturing of goods and materials, employment generation etc. have been most adversely affected.
The impacts of COVID-19 in daily life which are extensive and have far reaching consequences have been divided into three categories by Haleem A-n et al are:

\section{(A) Healthcare}

- Challenges in the diagnosis, quarantine and treatment of suspected or confirmedcase

- High burden of the functioning of the existing medical system

- Patients with other disease and health problems are getting neglected

- Overload on doctors and other healthcare professionals, who are at a very high risk

- Overloading of medical shops

- Requirement for high protection

- Disruption of medical supply chain

(B) Economic

- Slowing of the manufacturing of essential goods

- Disrupt the supply chain of products

- Losses in national and international business

- Poor cash flow in the market

- Significant slowing down in the revenue growth

(C) Social

- Service sector is not being able to provide their proper 
service

- Cancellation or postponement of large-scale sports and tournaments

- Avoiding the national and international travelling and cancellation of services

- Disruption of celebration of cultural, religious and festive events

- Undue stress among the population

- Social distancing with our peers and family members

- Closure of the hotels, restaurants and religious places

- Closure of places for entertainment such as movie and play theatres, sports clubs, gymnasiums, swimming pools, and so on.

(https://doi.org/10.1016/j.cp.20

COVID-19 has become a global crisis, evolving at unprecedented speed and scale. It's creating a universal imperative for governments and organizations to take immediate action to protect their people. Accenture, a leading global professional services company, providinga broad range of services in strategy and consultancy, considers it the biggest global event — and challenge - of our lifetimes. As such, it is changing human attitudes and behaviors today and forcing organizations to respond. However, the need to respond won't end when the virus' immediate threat eventually recedes. Covid-19 has altered the human behavior and time has come to act. Accenture outlines the five major human implications to expect from people's behavior and practical steps:

1. The cost of confidence: The erosion of confidence will make trust way more importantthan ever before. This will necessitate a "trust multiplier" — action that, to be effective, rebuilds trust quickly and credibly. Focus will be on confidence-building through every channel. Justifiable optimism will sell well. All of this may change the nature of what we regard as premium products and services.

2. The virtual century: The enforced shift during the worst of the pandemic to virtual working, consuming and socializing will fuel a massive and further shift to virtual activity for anything. Anything that can be done virtually will be. Winners will be those who test and explore all of the associated creative possibilities.

3. Every business is a health business: The concerns about health amplified during the crisis will not ebb after it is over. Rather, health will dominate. A health economy willemerge with opportunities for all to plug into. Every business will need to understand how it can be part of a new health ecosystem that will dominate citizen thinking.

4. Cocooning: Desire for cocooning, along with opportunities for those with creative strategies to enable it, will move center- stage for the same reason. Winners will be those who zero their sights on the home. At the height of the crisis, many-workers, especially — are spending more time at home. After, this pattern will endure with meaningfulness and comfort carrying a price premium.

5. The reinvention of authority: A reinvention of authority is likely after the effect of travel limitations, self-isolation and lockdown officially mandated by many governments. This is likely to be the trickiest of the five human implications as its impact could go one of two ways. If governments get their handling of the crisis broadly right, expect top-down control to be back in fashion; if not, the reverse. Thisis likely to vary by geography. What role will companies play? (wWw.accenture.com)

The impact of COVID-19 has also been recorded in an increase of domestic violence and United Nations' Secretary-General Antonio Guterres, witnessed the "horrifying global surge", and called for a domestic violence "Ceasefire". (Wikipedia) Domestic violence and sexual exploitation rapidly increased during lockdown when households were put under strains due to security, health, financial worries, disrupted legal services, stress and uncertainty and confinement at home, restriction on any kind of movement isolated women and left unattended because all resources are diverted to deal with the pandemic.

COVID-19 has accelerated the use of ICT in teaching-learning process as a powerful alternative to traditional mode. Digital technologies can definitely play a crucial role in transforming learning, teaching and evaluative practices for teachers and students in a high- standard $21^{\text {st }}$ century education system. Most of the rich and technologically advanced countries are investing in the field of information processing and ICT as a key instrument and within the area of education in the learning-teaching process. Jamaluddin Mostafa et al made pertinent remark in the paper entitled "The role of ICT in learning-teaching process" in the World Scientific News: "in the modern world, thanks to ICT, we are faced with a new civilization based on which we can integrate our learning and teaching procedures while respecting cultural issues and objectives as well as approaches and thus attain new forms acknowledge production in more innovative forms by placing learners and instructors in the face of a larger part of empowerment, innovations and upgraded information along using limited classroomtimes optimally"(www.worldscientificnews.com).

Baisakhi Bhattacharjee and Kamal Dev has emphasized the, "role of ICT in $21^{\text {st }}$ Century's Teacher Education. It's because there is a technological gap between the progress of the society and instructional activities of the teacher in the classroom". (www.ripublication.com). Scott Frei Berger finds 5 emerging trends in $21^{\text {st }}$ Century Education: "1. App Innovation and Gamification 2. Digital Literacy 3. Library Media specialists 4. Self-Directed Professional Development and; 5. Collaborative Learning". (www.gettingsmart.com). It's true that with the technological changes the burden is shifted to educators and instructional designers. The challenge is to make the optimum use of new technologies while preparing students for productive lives in the $21^{\text {st }}$ century. J. Michael Spector finds three technologies highly promising in the current scenario-" (a) Massive Open Online Course (MOOC); (b) Personalized Learning and; (c) Game-based Learning". (www.ksu.edu.sa).By involving the students with recent pedagogical technologies and motivating them, we can better 
their learning habits over a period of time. Kelly Walsh finds 10 highly engaging uses of instructional technology in the classroom, along with dozens of tools and resources for implementation. Most of these involve free web based tools: "Interactive Collaboration, Gathering Feedback, Embedding Questions in Videos, Active Learning, Social Learning, Using Technology to Help to Ensure Engagement with Digital Content, Student Created Presentations, Project Based Learning, Digital Makerspaces and; Flip Your Class to Free Up Class Time for More Engaged Learning". (www.emergingedtech.com). In an article entitled "Emerging technologies as pedagogical tools for teaching and learning science: A Literature review" Alando Oliveira et al consider the following emergent technologies the most significant for teaching and learning science: "(a) computational thinking; (b) simulations, dynamic visualizations, and virtual labs; (c) computational modelling; (d) mobile devices; (e) pedagogic robotics; (f) gaming and technology-mediated play; and (g) creative and artistic technologies". (wileyonlinelibrary.com).

COVID-19 has adversely affected all sectors around the world and education is no exception. Indian education system also faced severe lockdown and around 32 crore learners were compelled to remain at home and all sorts of educational activities suspended for long. But the outbreak of COVID-19 has taught us to accept that change is the law of nature and educational institutions should be ready to acknowledge it as an opportunity as well as challenge. Privat Kumar Jena considers this change, “ as a catalyst for the educational institutions to grow and opt for platforms with technologies, which have not been used before. The education sector has been fighting to survive the crises with a different approach and digitizing the challenges to wash away the threat of the pandemic" (www.journalera.com). Such challenges and opportunities have helped to strengthen the technological knowledge base and infrastructure of the educational institutions. Nevertheless, Deepali \&Gayatri consider, "COVID-19 has prompted experts to rethink the conventional mode of education. Digital education appears to be a viable solution to fill in the void for classroom education. It has brought the hitherto peripheral issue of digital education in India to the centre stage. Going forward, digital education is likely to be integrated into mainstream education. This will enable inclusive education by facilitating learning across diverse geographies in India. Moreover, it will provide an opportunity for educators to come up with customized learning solutions for every student". (LatestLaws.com)

NAMODI Framework is a part of Digital India Institute which aims to connect the entire nation digitally and make available all sorts of information online for all the sections of the society. This framework is a three layered architecture and has been designed to suit the needs of the deprived sections of the society. NAMODI Framework comprises of big data cloud project which contains massive online content and can be accessed from any part of the world. The specialty of the big data project is that the enormous amount of data can be uploaded through this platform and be made available to all the sections of the society. Digitization of Indian Education System through Massive Online Content Development, Technology Development, Apps Development, Data Analysis, Procedures, Outcome Measures, Conditions of the Testing, Social Treatments, Research Design etc. are the integral part of NAMODI Framework

(igntu.ac.in/Seminars/NEP_NAMODI)

With a view to frame an all-inclusive educational tune with the digital revolution for better utilization of Digital India Infrastructure for its implementation, to implement and bring the entire education domain from across India to one common platform, the concept of NAMODI Framework will be developed. To revolutionize educational system in a digital format is a step forward to transform Indian Educational System into Digital Education System. NAMODI Framework has become imperative to make our education more accessible and affordable. The Framework utilizes web 2.0 Cloud Computing and Big Data Technology so that the size of the architecture of this frame could be of nano size. This will enable the people to have accessibility to the study material in the form of Mobile Apps, digital tutors, E-Books, and thereby transform traditional educational Institutions into Digital Institutes.

India has the third largest educational system in the world next only to U.S.A. and China. Higher education is crucial to develop knowledge-based society and important tool to mound the socio-economic and cultural shape of the country; it contributes to the growth of the nation by providing specialized knowledge and skilled manpower. The core mission of higher education, according to Ramamurthy Naidu and Shakeel Ahmad is, "to Educate, Train, Undertake Research, and provide Service to community". ( $p$ 25) A.D.N. Bajpai and Rama Devi Rani extend the notion further: "Higher Education contributes to development ofa nation in several ways - as a productive resource in scientific research and industrial technology; as a catalyst for social change and economic development; and as a basis for civilization and cultural values that promote social integrity and harmony, which is essential for any nation to develop". (p7) But in the changed scenario, new challenges are emerging-students puffed with new aspirations and expectations, flux of technological innovations, process of globalization, dismantling the geographical boundaries, need of world class education and employability are the prerequisites of knowledge society. Ramachandran Tekamah has justly analyzed the role of higher education in the modern context: “Today's challenging economic situation warrants that it is no longer sufficient for a graduate to have knowledge of an academic subject; increasingly it is necessary for students to gain employability skills. It means that courses should be designed to suit the needs of the professions and that curricula should have the right mix of theory and practice". ("Guest Editorial") Naidu and Ahmad have explored the major concerns of Indian Higher Education during the XI Plan are, "Access and Expansion, Equity \& Inclusion, Quality and Excellence, Relevant Education and Quality Research", but in the present competitive world they opine: "Quality has become the key word in higher education. Globalization of the economy has also thrown up new challenges and hence quality 
improvement has become the biggest challenge before the higher education system. Access to the global economy will depend more on the quality and skilled productivity than on low labor costs". (p25)

To attain above objectives, higher education system requires qualitative rather than quantitative advancement that will emanate from certain innovations-which means nothing but introducing something new that makes the system better than the earlier. Even U.G.C. hasrealized the concern of the quality in Indian Higher System: "Quality and excellence couldn't be attained overnight. Organized and focused efforts are needed to achieve this goal. The unplanned growth of higher education coupled with lack of resources affects the quality of education. A careful distribution of resources is mandatory to achieve quality and excellence along with access and equality". ("Quality Assurance") The U.G.C. has taken upon itself this onerous task and has succeeded in maintaining the quality of education. It has launched manyschemes, which have made some impact in the system i.e. (1) Innovative Programmed including Emerging Areas (2) International Cooperation (3) Identification of Universities and Colleges with Potential for Excellence (4) Networking of Universities and Colleges (5) Faculty Improvement Programmed (6) National Eligibility Test (7) Schemes for strengthening of Research (8) Programmed for the development of Engineering and Technical Education (9) Programmed for the development of Management Education (10) Programmed for the development of Computer Education and Upgradation/Augmentation of Computer Facilities and; (11) Accreditation System.

To restrict such currency devaluation, small and big ones, there is an immediate need for putting in place a Scientific Thought Revolution which has already commenced through 'Make in India', 'Skill India' 'Start Up India' and 'Digital India' process initiated by the Govt. of India. For this purpose, the digitalized educational system should be in tune with the demand of changing times and should be progressive, inclusive and composite in nature. The impartial theme of the research on NAMODI (Nano Architecture Mobile Oriented Digital Institutes) framework is to bring the entire educational aspects and teachinglearning activities to a common digital platform.

According to the demographic composition of India by 2030, our country will be one among the youngest nations in the world. With nearly 140 million people in the college-goingage group, one in every four graduates in the world will be a product of the Indian higher education system. By 2030, the already existing challenges for Indian higher education - access, equity and quality - will only be greatly aggravated unless it significantly transforms our higher education model.

\section{Digitization of Indian Education System}

Innovation and technology have been game changer in every sector in India Technology has made everything much easier and faster, and it has compelled almost all the sectors of economy to adapt to change or fear to become obsolete. In this pace of digitalization, it has also become imminent for our education sector to adopt a dynamic environment and change itself, as it allows it to keep pace with a competitive world. The Western education system in India was introduced during British regime. However, while the British government has experimented and evolved ways of learning, the Indian education system still lags behind. Teaching is still conducted in old-fashioned classrooms with rigid syllabi dominating the curriculum. Mainland, Founder \& CEO, Guru Q has rightly foresees the power of modern innovation and technology in education system:

...digitalization offers fluidity to the Indian education sector by being a supplementary form of the system as it is available to students as per their need. While the traditional education system has a uniform approach, EdTech can be customized as per students' requirements. It can be molded as per the student's capability to understand and imbibe any particular subject. Secondly, as the world is moving towards digitalization has no option but to keep pace with it. We know that the traditional education system in India is here to stay for the long haul and that no one can take away that learning experience. But our education system needs to be dynamic and needs to adapt to technology. (www.entrpreneur.com)

There is no need to fear a subject like math's as there are fun ways to learn it with the use of EdTech. Today there are apps to learn languages or any other subject. Hence, what is the point in learning a traditional system when there are so many impactful means of learning through digitalization? Anand continues:

Thirdly, digitalization brings in a more practical approach of tracking students'performance. One can easily evaluate a child's progress by going through his examscores, attendance, assignments, etc. For instance, one has a choice to choose a tutor,schedule class as per one's time availability and study offline or online as per theirconvenience. In today's world where time is money, digitalization is a big-time saver. Apart from metros, there are many tier II and tier III cities where transport system isnot fully developed. Students have to commute for hours to reach their educationalinstitutes. In this scenario, a digital course comes as a rescuer to students from eventhe remotest parts of the country. One just needs to log into a website or switch ontheir dish TV channel to learn a subject rather than spend long hours in the commutefrom one spot to another. Lastly, digitalization offers a safe mode of learning which istransparent and accountable. Parents can keep a track of their wards' progress bylogging into the website. It also offers them a platform to air their views andsuggestions which can be used to improve the system, unlike the traditional methodwhere one has to be quiet fearing reprimand from the teacher. Digitalization help in creating a solid partnership between parents and teachers with one goal in mind -better learning for students. (ibid)

Prof Nivedita Jha and Prof Veena Shenoy find digitization of Indian education system a second revolution in the history of education: "Printing press changed the world of education forever. Six centuries later we are undergoing another 
transformation and this time everything is going digital" ( www.iosrjournals.org).

The $21^{\text {st }}$ century has witnessed phenomenal growth in technology especially relevant to education sector. Smartphones, laptops, and tablets are very common devices and quite familiar words. With the phenomenal growth of technology, mode of education, pedagogical technologies are also changing. If we go on teaching our students with old methods it means we are going to restrict them for future technological advancements. Our old educational system has no capability to stand a chance in the 21 st century. So we are compelled to use digitization in our educational system. Technology can become the 'wings' that will allow the educational world to fly farther and faster than ever before; if we will allow it. Janetta Ainsley her article "Digitization Of Education In The 21st Century" has observed the evolution of the educational industry. She describes the era of 21 st century in terms of educational progress and how the 'old school' systems became the 'new school' systems that boosted digital education:

Digitization is the integration of digital technologies into everyday life by the digitization of everything that can be digitized. Yes! Digitization is the trending term, describing the 21 st century in the most precise manner as possible. We are in the era where unprecedented ideas are unfolding in our education industry and creating the advancement that can't be matched by lagging behind in terms of technology. The newphase of learning has begun and involves various advanced techniques like: Online Courses, Online Exams, digital Textbooks (e-textbooks and e-texts other name), animation, accumulation of students on the same platform, Online Resources: Connecting Students with Their Educators, Internet: Making Digitization Possible, Administrative Activities: An Integral Part of The Education Industry. And she concludes:

Digitization has no doubt changed our education system, but we cannot say that it has diminished the value of our old-time classroom learning. Neither do we want something so priceless to turn into dust. The best part about the digitization of education in the $21 \mathrm{st}$ century is that it is combined with the aspects of both; classroom learning and online learning methods. Walking hand in hand both act as a support system to each other, which gives a stronghold to our modern students. Digitization ineducation has also proved to be the right method for saving resources. Online examination platforms have restricted the frivolous usage of paper, directly confining the cutting down of trees. This way the digitization of education industry in the 21 st century proves to be a boon to our society. (elearningindustry.com)

\section{REFERENCES}

1. Aggarwal, J.C. Educational Planning, Budgeting and Financing in India. New Delhi: Arya Book Depot, 1995.

2. Ainslee, Janetta. "Digitization of Education in the 21 st Century" <elearningindustry.com> Anan,Minal. "How Digitization Can Change the Indian
Education system" $\langle$ www.entrepreneur.com $>$

3. Bajpai, A.D.N. and Pani, Sistla Rama Devi. "Reforms and Innovations in Higher Education: Breaking New Grounds", University News, Special Issue on Reforms and Innovations in Higher Education: A March Towards World Class Standards, Vol. 49, No 50, December 12-18, 2011.

4. Bhattacharjee, Baishakhi and Deb, Kamal. "Role of ICT in 21st Century's Teacher Education” International Journalof Education and Information Studies

5. 〈http://www.ripublication.com>

6. Big Dataattunelive.com/big-data applications-healthcare

7. Choudhary, Richa. "COVID-19 Pandemic: Impact and Strategies for education sector in India" $<E T$ Government.com>

8. "COVID-19: 5 new human truths that experiences need to address $<w w w$. accenture.com> Freiberger, Scott. "5 Emerging Trends in 21 st Century Education"

9. <https://www.gettingsmart.com>

10. Haleem A- $n$ et al. "Effects of COVID-19 pandemic in Daily Life" in Current Medicine Research and Practice <https://doi.org/10.1016/j.cmrp.2020.03.011.

11. "Impact of the COVID-19 pandemic on domestic violence" <Wikipedia> jagranjosh.com/generalkowledge/summaryon-the-history-of-modern-education-during- british-india

12. Jha, Nivedita \& Shenoy, Veena. "Digitization of Indian Education System: A Hope or Hype"IOSR Journal of Business and Management (IOSR-JBM) e-ISSN: 2278487X, p- ISSN: 2319-7668. Volume 18, Issue 10. Ver. III (October. 2016), PP 131-139

13. 〈www.iosrjournals.org>

14. Kasrekar, Deepali \&WadhavaneTapaswi, Gayatri. "Impact of COVID-19 on Education System in India" $<$ LatestLaws.com $>$ Kothari, C.R. \& Garg, Gaurav. Research Methodology: Methods and Techniques. (thid Edition), New Delhi: New Age International (P) Ltd, 2014.

15. Kumar, Ranjit. Research Methodology:A Step by Step Guide for Beginners. (Second Edition), Pearson, Fifteenth Impression, 2014.

16. Lal, Raman Behari\& Sinha, G.N. Development of Indian Education and Its Problems.

17. (Second Edition) Meerut: R. Lall Book Depot, 2007.

18. Madsen, Laura B. Data-Driven Healthcare: How Analytics and BI are Transforming the Industry. Wiley India Pvt. Ltd., 2015.

19. Mostafa, Jamalahdin et al. "The role of ICT in learningteaching process" in World Scientific News $\langle$ www.worldscientificnews.com>

20. Nagata, Sharon. <https://elearningindustry.com/trends-ineducation-technology-modern- society>

21. Naidu, Ramamurthy $K$ and Ahmad, Shakeel. "Quality Concerns in Higher Education" University News, Special Issue on Reforms and Innovations in Higher Education: A March Towards World Class Standards, Vol. 49, No. 50, December 12-18, 2011.

22. NAMODI< igntu.ac.in/Seminars/NEP_NAMODI_Seminar July 16,pdf)

23. National Education Policy 2020: Ministry of Human Resource Development, Govt of India, Chapter-23 \& 24, pp 56-58.

24. Oliveira,Al and eometal. <wileyonlinelibrary.com/journal/hbe2> "Quality Assurance" www.ugc.ac.in

25. Sayingtruth.com/top-mobile-apps

26. Spector, Michael J. "Emerging educational Technologies:Tensions and Synergy"

27. 〈www.ksu.edu.sa> 
28. Thekkedath, Dr.Ramchandran. "Guest Editorial" University News, Special Issue on Reforms and Innovations in Higher Education: A March Towards World Class Standards, Vol. 49, No 50, December 12-18, 2011.

29. theindianwire.com/education/bestandroid-education

30. Walsh, Kelly.

<https://www.emergingedtech.com/2014/09/most-

engaging-uses-of- instructional -technology>

31. http://www.healthcatalyst.com/bigdata-n-healthcare-madesimple $\quad w w w$.datapine.com/blog/bigdata examples- $n$ healthcare

32. http://mapr.com/blog/5-bigdata-trends-healthcare-2017 www.indiatoday.inwww.edsys.in/12-benefits-of-using-appsin-education https://www.researchgate.net https://guides.umd.umich.edu

33. https://www.enago.com>academy>identifying-researchgaps https://diksha.gov.in

34. https://epathshala.nic.in www.swayam.gov.in www.swayamprabha.gov 